\title{
The efficacy of a voluntary summer book reading intervention for low-income Latino children from language minority families.
}

\section{Citation}

Kim, James S., and Jonathan Guryan. 2010. The efficacy of a voluntary summer book reading intervention for low-income latino children from language minority families. Journal of Educational Psychology 102, no. 1: 20-31.

\section{Published Version}

doi:10.1037/a0017270

\section{Permanent link}

http://nrs.harvard.edu/urn-3:HUL.InstRepos:28983160

\section{Terms of Use}

This article was downloaded from Harvard University's DASH repository, and is made available under the terms and conditions applicable to Open Access Policy Articles, as set forth at http:// nrs.harvard.edu/urn-3:HUL.InstRepos:dash.current.terms-of-use\#OAP

\section{Share Your Story}

The Harvard community has made this article openly available.

Please share how this access benefits you. Submit a story.

\section{Accessibility}


Running head: VOLUNTARY SUMMER BOOK READING

The Efficacy of a Voluntary Summer Book Reading Intervention for Low-Income Latino Children from Language Minority Families

James S. Kim

Harvard Graduate School of Education

Jonathan Guryan

University of Chicago Booth School of Business and NBER

(C) James S. Kim

CITATION: Kim, J.,S. \& Guryan, J. (2010). The efficacy of a voluntary summer book reading intervention for low-income Latino children from language minority families. Journal of Educational Psychology, 102(1), 20-31. 


\begin{abstract}
The effects of a voluntary summer reading intervention with and without a parent training component were evaluated with a sample of low-income Latino children from language minority families. During the last month of fourth-grade, 370 children were pretested on a measure of reading comprehension and vocabulary and randomly assigned to (1) a treatment group in which children received 10 self-selected books during summer vacation, (2) a family literacy group in which children received 10 self-selected books and were invited with their parents to attend 32 hour summer literacy events, and (3) a control group. Although children in the treatment group and family literacy group reported reading more books than the control group, there was no significant effect on reading comprehension and vocabulary. Recommendations for improving the efficacy of the intervention are discussed, including efforts to improve the match between reader ability and the readability of texts and the instructional goals of the family literacy events.
\end{abstract}

Keywords: voluntary summer reading, text readability, language minority children, family literacy, randomized experiments 
The Efficacy of a Voluntary Summer Book Reading Intervention for Low-Income Latino

\section{Children from Language Minority Families}

Low-income Latino children growing up in language minority families are at-risk of falling behind in reading during summer recess. On average, summer vacation creates a three month gap in reading scores between middle- and low-income children (Cooper, Nye, Charlton, Lindsay, \& Greathouse, 1996). O’Brien (1999) analyzed reading comprehension scores for three cohorts of elementary school children (Grades 3, 4, 5) in a Texas school district and found that the gap between Latino and White children widened over three consecutive summers; moreover, low-income Latino children underwent larger reading losses than middle-income Latino children. Why do low-income Latino children from language minority families fall behind in reading during summer vacation?

Social scientists have proposed two explanations to address this question. First, sociologists have found that children growing up in low-income and working-class families own fewer books and spend less time discussing books with their parents than children from middleincome families (Burkam, Ready, Lee, \& LoGerfo, 2004; Entwisle, Alexander, \& Olson, 2000; Lareau, 1989). During summer vacation, children rely heavily on their parents and families to provide books and opportunities to read at home. Low-income parents, however, often lack the resources to buy a sufficient number of books that are appropriately challenging and interesting for their children (Chin \& Phillips, 2004). Given limited opportunities to read books independently and with their parents, many low-income children are at-risk of falling behind in reading during summer vacation. Second, psychologists have suggested that frequent practice is critical for children who are in the early stages of acquiring a skill (J. R. Anderson, 1995; Brynes, 2000). For example, children who are learning English at school while growing up in 
Spanish-speaking homes need extensive practice to maintain their ability to read text with fluency and comprehension and to retain their knowledge of English vocabulary during summer recess. According to the Simple View of Reading (Gough \& Tunmer, 1986), practice decoding words and hearing new words are both critical to improving reading comprehension. Without additional training, however, many Spanish-speaking parents may be unable to help their children read and understand new words in English. Since children from language minority families may have limited opportunities to read, hear, and speak English at home during the summer, Cooper et al. (1996) predicted that "summer break would be especially detrimental to students who speak a language at home that is different from the language of school instruction" (p. 261). Thus, many low-income Latino children from language minority families may fall behind in reading during summer vacation because of their limited access to books at home and limited opportunities to practice English with family members.

The purpose of this study was to prevent summer reading loss by replicating the effects of a voluntary summer reading intervention among low-income Latino children from language minority families. One strategy for preventing reading loss is to send books to children's homes and to encourage independent reading during summer vacation. A large literature seems to support such an intervention strategy. Whether measured through reading diaries, self-reported surveys, or the Title Recognition Test, reading volume has been shown to exert a positive influence on reading comprehension gains in the upper elementary and middle grades (Allen, Cipielewski, \& Stanovich, 1992; R. C. Anderson, Wilson, \& Fielding, 1988; Cunningham \& Stanovich, 1990, 1991; Hofferth \& Sandberg, 2001). In a longitudinal study involving 1,128 sixth- and seventh-grade students, Heyns (1978) found that the number of books read and time 
spent reading predicted reading gains during summer vacation controlling for prior reading ability, family income, and parent education.

Correlational evidence, however, does not imply that intervention efforts to increase print exposure will cause improvements in reading comprehension. The National Reading Panel (National Reading Panel [NRP], 2000) found few experimental studies on the effects of voluntary reading activities like sustained silent reading, in which children receive little or no guidance selecting books or monitoring their comprehension of text. Since the NRP report, reading researchers (RAND Reading Study Group, 2002; Stahl, 2004) have suggested that increasing print exposure is a necessary but not sufficient part of interventions designed to improve reading comprehension. In addition to increasing print exposure, there are several ways to improve the potential effectiveness of a voluntary summer reading intervention.

First, the effectiveness of a voluntary summer reading intervention may depend on the ability of readers to decode words and to comprehend text independently. Chall's (1983) stage theory of reading suggests that children in grades 4 and above are more likely than younger children to have sufficiently strong decoding skills to read books independently without the assistance of teachers or parents. Decoding ability functions like a "built-in teacher" (Share, 1995) that enables children to decipher unfamiliar words and to read and understand text independently during silent reading (Bowey \& Muller, 2005). Many children in the early elementary grades, however, have weak decoding skills and may not benefit from voluntary reading activities, in which teachers, parents, or tutors provide little or no assistance identifying words (NRP, 2000).

Second, the effectiveness of a voluntary summer reading intervention may depend on the match between reader ability and the readability of texts. Reading scholars have suggested that 
reading comprehension is enhanced when texts are matched to a child's independent reading level (Carver, 1994; Wright \& Stone, 2004). Experimental studies suggest that children do not enjoy comprehension gains from reading poorly matched books (Carver \& Leibert, 1995; O'Connor, Bell, Harty, Larkin, Sackor, \& Zigmond, 2002). Until recently, however, reader ability and the readability of texts have been measured on separate scales, making it difficult to match children to appropriately challenging books (Fry, 2002; U. S. Department of Education, 2001). To overcome this methodological challenge, the Lexile framework uses a Rasch model to place measures of reader ability and the readability level of texts on a common scale (Rasch, 1980). In theory, if reader ability exceeds the readability level of text, there is a higher probability that children will comprehend texts and learn new words through reading (R. C. Anderson \& Nagy, 1993; Nagy, Anderson, \& Herman, 1987). In addition, since children are unlikely to know the meaning of all the words in a book, they need to infer word meanings from context (Nagy \& Scott, 2000). Reading text with a low density of unknown words is likely to aid comprehension; however, reading text with a high density of unknown words is likely to impede comprehension (Swanborn \& de Glopper, 1999). To help children improve their comprehension of texts, researchers and educators can use Lexiles scores to determine whether the readability level of a book is matched to a child's independent reading level (Schnick \& Knickelbine, 2000).

Third, the effectiveness of a voluntary summer reading intervention may depend on the reading strategies that children learn to use while reading books independently and with family members. For example, the National Reading Panel (2000) suggested that "independent silent reading is not an effective practice when used as the only type of reading instruction to develop fluency and other skills" (p. 13). Teachers can play a key role in scaffolding voluntary reading by helping children read text fluently and self-monitor their comprehension (Brynes, 2000; Stahl, 
2004). Meichenbaum and Biemiller (1998) define scaffolding as "the practice of providing just enough assistance (not too much or too little) to help students succeed" (p. 141). Right before summer vacation, teachers can scaffold voluntary reading by encouraging children to read aloud with their parents, instructing children to use multiple strategies for comprehending text, and releasing responsibility to children for practicing these strategies while reading books at home. Oral reading activities may improve fluency and comprehension by helping children read with greater accuracy, speed, and prosody (Daane, Campbell, Grigg, Goodman, \& Oranje, 2005; Fuchs, Fuchs, Hosp, \& Jenkins, 2001). Multiple comprehension strategies, such as question generating, question answering, summarizing, and re-reading, can help children understand and retain information from reading books independently (Pearson \& Fielding, 1991; RAND Reading Study Group, 2002; Rosenshine, Meister, \& Chapman, 1996).

How, then, do we design a voluntary summer reading intervention that addresses the complex interactions among readers, texts, and comprehension activities? We explored the importance of each of these components in three previous experimental studies. Our first experimental study (Kim, 2007) tested the hypothesis that a voluntary summer reading intervention could promote larger comprehension gains among children in the upper elementary grades ( 3 to 5 ) than the early elementary grades ( 1 to 2$)$. In one elementary school, 331 children in grades 1 to 5 were randomly assigned to receive 10 books matched to their reading level in the summer (treatment group) or in the fall after the administration of posttests (control group). Although the treatment by grade interaction was not significant due to limited power, the magnitude of the estimated treatment effect was larger in the upper grades than the lower grades, and the intervention increased children's summer reading activities. The results of this study tentatively supported the hypothesis that a voluntary summer reading intervention could be 
effective for children in the upper elementary grades and informed a power analysis for a larger experiment.

Our second experiment involved over 500 Grade 4 children and tested the hypothesis that scaffolding voluntary reading with appropriately difficult text and teacher-directed instruction could improve reading comprehension (Kim, 2006). Using the Lexile framework, we matched eight books to each child's independent reading level. In addition, books were matched to children's reading preferences, which were obtained through a reading survey. We controlled text comprehensibility by using a computer algorithm to match books to readers so that the readability level of each book was within each child's independent reading level. Two weeks before summer vacation, teachers instructed children to use multiple comprehension strategies (Rosenshine \& Meister, 1994) while reading books independently and oral reading activities (Koskinen \& Blum, 1986) while reading books with family members. Children were randomly assigned to receive books in the summer or fall after posttesting; books and reading postcards were also mailed home to encourage children to follow through on the reading lessons taught by their teachers. The results revealed positive and significant improvements in reading comprehension and the frequency with which children read with their parents and family members. Therefore, the results suggested that the effects of a voluntary summer reading intervention could be enhanced by matching appropriately challenging books to children and by instructing children to use comprehension strategies while reading books at home. However, the results left unanswered the question of whether increasing print exposure alone or in combination with teacher-directed instruction caused these improvements in reading comprehension. 
Our third experiment was designed to test the value-added contribution of the teacherdirected lessons on reading comprehension gains relative to increasing print exposure during summer vacation. Thus, the third experiment involved the random assignment of both teachers and children to one of four conditions: control, books only, books with oral reading scaffolding, and books with oral reading and comprehension scaffolding. The results showed that children in the books with oral reading and comprehension scaffolding group scored significantly higher than the control group and marginally higher than children in the books only condition (Kim \& White, 2008).

\section{Study Goals and Hypotheses}

This study was designed to extend our previous work in three ways. First, we examined whether the effects of a voluntary summer reading intervention could be replicated outside the Virginia school district where the intervention was designed and field-tested. To evaluate the efficacy of the treatment in a high-poverty district in California, we compared outcomes for the control group and the treatment group children, who received books with oral reading and comprehension scaffolding lessons (Kim et al., 2008). We hypothesized that children in the treatment group would enjoy significant gains in reading comprehension and reading activities relative to the control group, replicating positive effects in the California school district.

Second, we examined whether treatment effects could be enhanced with a family literacy intervention in which parents were instructed to use comprehension strategies with their children. In our previous studies, a majority of the parents were native English speakers and were not instructed to ask comprehension questions while their children read books at home. In this study, however, virtually all parents were non-native English speakers. Given the limited English proficiency of the parents in this study, we wanted to instruct parents in their native 
language to use comprehension strategies that children had learned in school. Research suggests that language minority parents are motivated to support their children's literacy activities at home by asking open-ended questions that help their children comprehend text and by engaging in conversations about books with their children (Debruin-Parecki, 2007; Goldenberg, Rueda, \& August, 2006). We hypothesized that children in the family literacy intervention would enjoy greater improvements in reading comprehension and reading activities relative to the treatment group as well as the control group.

Third, given the voluntary nature of participation in the intervention activities, we examined the amount of variance in scores at posttest explained by reports of books read and participation in the family literacy events. Furthermore, because students were allowed to select their own books for this study, we also examined the relationship between the relative difficulty of the books they were given and posttest comprehension and vocabulary scores.

Method

Participants. All children in our study attended a public school district in California with a total K-12 enrollment over 50,000 students. Over $90 \%$ of the children in the study were Latino/a, received a free lunch subsidy, and came from homes where Spanish was the primary language spoken by parents.

Design. In May 2007, we recruited 400 Grade 4 children from four elementary schools and $370(93 \%)$ received parental consent to participate in the study. Participating children were administered pretests and underwent random assignment to 1 of 3 experimental conditions. The three experimental conditions included (1) a treatment group in which children received 10 selfselected books in the mail, (2) a family literacy group in which children received 10 self-selected books in the mail and were invited with their parents to attend 3 2-hour family literacy events, 
and (3) a control group in which children received 10 self-selected books after posttests. Children who remained in the study at posttest were administered reading tests and surveys in the second week of September 2007 at the beginning of fifth-grade. Random assignment of children to experimental conditions improved internal validity and statistical power. First, teachers were blind to each child's condition, because the implementation of the family literacy events and book mailings occurred during summer vacation. Second, we increased power by using individual students rather than intact classrooms as the unit of random assignment.

Although $12 \%$ of the original sample was lost to attrition, results of a chi-square analysis revealed no significant relationship between the experimental conditions and attrition rates among the three groups, $\chi^{2}(2,370)=2.134, p=.344$. These results suggest that differential attrition by treatment conditions did not threaten the internal validity of the findings. Among the children who remained in the final sample at posttest, there was no significant difference on the mean pretest reading scores among the three conditions, $F(2,315)=.95, p=.387$. Table 1 displays the demographic characteristics of the 325 children who remained in the final sample at posttest. Chi-square analyses revealed no statistically significant relationship between the experimental conditions and each of the demographic characteristics. Descriptive statistics for mean reading scores by condition for children in the final sample are shown in Table 3.

\section{Measures}

Student demographic variables. We obtained student demographic data from district administrative files, including gender, ethnicity, the primary language spoken at home, family structure, free lunch status, and age (in months).

English language learner status. Information on whether a child was an English language learner was also included in the district administrative file. In California, districts 
implement two procedures to identify English language learners. First, parents are required to complete a language survey upon enrolling their child in a public school. If the home language is not English, children are administered the California English Language Development Test (CELDT), which measures a child's proficiency of English language skills in listening, speaking, reading, and writing (California Department of Education, 1999). Each section of the CELDT contributes equally to the overall proficiency level. There are five proficiency levels on the CELDT, and children scoring in the lowest three levels-beginning, early intermediate, and intermediate — are classified as English language learners. In our sample, $73 \%$ of the children were English language learners.

Gates-MacGinitie Reading Test (GMRT). We administered the Gates-MacGinitie Reading Test (GMRT), Level 4, Form S, at pretest and Level 4, Form T at posttest. Recently normed in 2005, the Gates-MacGinitie Reading Test includes a total reading score based on a 48 item comprehension subtest and a 45 item vocabulary subtest. The KR-20 reliability coefficient for the GMRT Level 4 is .96 , and test-retest reliability is .92 . At pretest, the GMRT comprehension scores were converted to Lexiles (Maria, Hughes, MacGinitie, MacGinitie, \& Dreyer, 2007), which yielded a measure of reader ability that was on the same scale as the mean readability level of the 10 books chosen by each child during a school bookfair.

Text Comprehensibility. We created a text comprehensibility score for each child, which captured the difference in Lexile units between reader ability at pretest and the mean readability level of each child's 10 self-selected books. In Lexiles, the text comprehensibility score $(M=-64, S D=151, \operatorname{Min}=-645, \operatorname{Max}=488)$ captured the difference between the Lexile for reader ability $(M=571, S D=147, \operatorname{Min}=75, \operatorname{Max}=1,025)$ and the mean Lexile level for the 10 books $(M=636, S D=69, \operatorname{Min}=417, \operatorname{Max}=843)$. For the sample, the mean Lexile score of 
571 for reader ability corresponded to a mean Grade Equivalent (GE) score of 3.4. Given the mean Lexile score of the 10 books matched to the children, the readability level of the books would be appropriately challenging for children who scored at or above a GE of 3.6.

Independent book reading during summer vacation. To obtain information on independent reading during summer vacation, we asked children "about how many books did you read during the summer?" Response options included (1) 0-1 book, (2) 2-3 books, (3) 4-5 books, (4) 6-7 books, (5) 8-9 books, or (6) 10 or more books.

Frequency of book reading with parents during summer vacation. To obtain information on the frequency with which children read books with their parents, we began by asking children "during summer vacation, how often did you read books with your mother?" In addition, children were asked, "during summer vacation, how often did you read books with your father?" For each item, response options were (1) never or hardly ever, (2) once or twice a month, (3) once or twice a week, or (4) almost every day.

\section{Procedure}

All four schools in our study followed the Open Court pacing guide until the administration of the California Standards Tests (CST) in English language arts. After state testing was completed, we implemented the three procedures described below.

1. Teacher training and classroom lessons. During the third week of May, Grade 4 teachers attended a 2-hour training session to learn how to implement the reading lessons. Training was conducted by two veteran teachers who had taught for over 10 years in the California school district. The lesson plans were based on the work of a team of educators in the Virginia school district where the intervention was field-tested in the earlier experiments (Author 2006, 2008). The script used during training instructed children how to use multiple 
comprehension strategies while reading a fiction book (My Rotten Red-Headed Older Brother) and a non-fiction book (I Wonder Why Snakes Shed Their Skin) and how to read aloud from books with family members.

The two trainers modeled a series of three lessons with each book for a total of six lessons. As part of the lessons, the trainers instructed participating teachers in this study to implement a homework assignment using reading postcards. In the postcard activity, teachers read aloud from the fiction and non-fiction book and instructed children to answer six questions on a reading postcard. The questions on the postcard asked children to write down the book title, whether they finished the book, how many times they read the book, and whether they used five comprehension strategies to better understand the book, including re-reading, summarizing, making predictions, asking questions, and making connections (text to text, text to self). The last two questions asked children to select a 100-word passage from the book and then read aloud to a family member. After a second reading, children were prompted to ask a family member whether they read more smoothly, knew more words, and read with more expression. Additional details on the reading postcards are discussed in an earlier study (Kim \& White, 2008).

After teacher training, one rater observed at least one lesson in each of the 13 classrooms to assess lesson fidelity and quality. Lesson fidelity was measured on a 3-point scale (high to low fidelity). Lesson quality was scored on a 3-point scale (clear evidence to no evidence) to determine how well teachers (1) used think-aloud modeling during the comprehension lessons, (2) provided relevant examples related to each of the five comprehension strategies, (3) supported students during book selection, and (4) sought to engage all students during the lesson. Overall, the mean score on the fidelity measure $(M=2.67, S D=.49)$ and quality measure $(M=$ $2.79, S D=.24)$ indicated that most teachers adhered to the lesson scripts and implemented the 
lessons in their classrooms with moderate to high quality. Approximately $72 \%$ of the children in treatment group and family literacy group returned 1 or more postcards during summer vacation. On average, children in these two groups returned postcards for more than half of their 10 books $(M=6.09, S D=2.88)$. Children in the control group received their books and postcards after posttests. These data suggest that teachers implemented the reading lessons and children who received books in the summer were able to carry out the procedures for returning the postcard.

2. Fiction and non-fiction titles in the book fair. During the first week of June, the two teacher trainers selected 87 fiction books and 53 non-fiction books to be used in the classroom book fair. Although children did not participate in selecting the 140 titles, the two teacher trainers used Scholastic's 2006-07 Education Catalogue to identify popular children's books listed under "Award-Winners \& Favorites," "Authors Kids Love," and "Series \& Motivation." These collections included high-interest series books (e.g., Captain Underpants, Junie B. Jones, Jigsaw Jones), books about sports stars (e.g., NBA: Yao Ming, NFL Superstars) and historical figures (e.g., Abraham Lincoln, Leonardo Da Vinci), and natural science (e.g., Amazing Sharks, Science Experiments You Can Eat). Children participated in school book fairs where they were allowed to select their 14 favorite titles ( 7 fiction, 7 non-fiction). Each child received the 10 books which had Lexile levels closest to his/her Lexile level.

3. Summer family literacy events. Children and parents in the family literacy group were invited to attend three 2-hour literacy events - twice in July and once in August. The purpose of the family literacy event was to reinforce the district's Grade 4 English language arts curriculum (ELA), which focused on helping children use strategies to comprehend text. Since the California state ELA curriculum ends phonics instruction in third-grade, we did not train parents to use phonics to help their children decode words. Given the goals of the school curriculum, we 
emphasized the importance of acquiring meaning from print and encouraged parents to ask comprehension questions in their native language to help their children understand their books.

One week before each event, we notified parents through a letter translated in Spanish and then called parents the day before each event. To encourage attendance, we also included a dinner for participating families. After dinner, instructors began each event by explaining the goals of the event - to encourage families to have fun reading and discussing books at home and to use reading comprehension strategies that reinforced skills taught by teachers. After the introduction, children and parents watched a video showing adult-child dyads reading and discussing books. First, the video included a bilingual family in which a mother read a fiction book with her daughter, asked questions before, during, and after the reading, and re-read interesting and difficult passages. The mother-child dyad read a narrative book about the $4^{\text {th }}$ of July holiday and the mother also asked questions about the book before, during, and after the reading in English. Second, the video showed a father reading a non-fiction book about baseball with his son and engaging in a discussion about the book in Spanish. Similar to the motherdaughter dyad, the father prompted the son to think about questions to ask before, during, and after the reading. After viewing the videos, the instructors asked parents at the family literacy event to discuss and write down on a paper what they were able to "see" and "hear" the child and parent do during the reading. Next, instructors gave families an opportunity to read a fiction and non-fiction book in English and Spanish, to practice using the comprehension and oral reading strategies, and to complete the reading postcards used by teachers in their classroom lessons.

In the second and third sessions, the activities in the first lesson were repeated and parents were taught to use additional activities from the book, Family Time Reading Fun (Clinard, 2002), including listening and reading comprehension activities for the second sessions 
(e.g., Before, During, and After) and third session (e.g., Sentence Scramble). To practice these activities, parents and children were given English and Spanish copies of a fiction and nonfiction book during each session. Instructors reviewed portions of the video to review how to ask questions before, during, and after a reading of a book. In addition, families were taught to take text in English and Spanish from a storybook, to scramble the words, and then to place the words into meaningful sentences. As with the first session, these activities were selected because they reinforced the same reading comprehension activities implemented by classroom teachers during the last month of school.

Results

\section{Implementation Checks}

Our first implementation check examined the match between text comprehensibility and reader ability. A text comprehensibility score close to 0 indicated that the Lexile score for reader ability and the mean Lexile score for the 10 books was similar. A positive text comprehensibility score indicated that reader ability was above the mean readability level of the 10 books and a negative text comprehensibility score indicated that reader ability was below the mean readability level of the 10 books. In our sample, $33 \%$ of the children received books with positive text comprehensibility scores and $67 \%$ of the children received books with negative text comprehensibility scores. In other words, a majority of the children received books that were above their reading level and relatively difficult to comprehend. The strong positive correlation $(r=.90, p<.01)$ between text comprehensibility and reader ability suggests that good readers were more likely than poor readers to receive books with positive text comprehensibility scores.

Our second implementation check examined participation rates in the summer literacy events. Table 2 shows that $55 \%$ of the children in the family literacy group attended 0 events 
during the summer and only $16 \%$ of the children attended all three events. Therefore, a majority of the children did not attend a summer literacy event, suggesting that non-participants in the family literacy group received essentially the same intervention (i.e., 10 self-selected books mailed to their homes) as children in the treatment group. After our implementation analyses, we conducted three analyses to address our research questions.

\section{Treatment Effects}

First, we examined treatment effects on the Gates-MacGinitie Reading Test total score and separately for comprehension and vocabulary. Because prior research suggests that reading comprehension and vocabulary respond differently to summer reading interventions (Cooper et al., 1996; Phillips \& Chin, 2004), omnibus multivariate tests were not appropriate for our analyses (Rosenthal \& Rosnow, 1991). Therefore, we conducted ANCOVA on each of the three GMRT posttests with pretest scores serving as the covariate. Second, we used non-parametric tests (Kruskal-Wallis) to examine group differences on the ordinal measures of summer reading, including the number of books children reported reading and the frequency with which children read books with their parents. Third, we used multiple regression analysis to examine whether variability in posttest comprehension and vocabulary scores was explained by children's selfreported measures of book reading, participation in the summer literacy events, and text comprehensibility after pretest vocabulary scores and English language learner status were statistically controlled. Since text comprehensibility is based on the difference between the pretest comprehension score and the mean readability of level of each child's 10 self-selected books, we avoided multicollinearity by using the vocabulary score as the pretest measure in the regression analyses. 
Question 1: Do children in the treatment group and the family literacy group score higher on measures of reading comprehension and vocabulary than the control group? Are there significant differences between the treatment group and the family literacy group?

Table 3 displays the means and standard deviations of the pretest and posttest reading comprehension scores on the Gates-MacGinitie Reading Test (GMRT) by condition. For the sample, GMRT total scores declined from the $24^{\text {th }}$ percentile on the June pretest to $18^{\text {th }}$ percentile on the September posttest, providing clear evidence of decline in reading comprehension and vocabulary during summer vacation. ANCOVA on the total reading scores revealed a nonsignificant main effect of condition, $F(2,307)=.40$, n.s., suggesting that there was no difference in covariate-adjusted total reading scores among children in the three experimental conditions. When we analyzed treatment effects by subtests on the GMRT, we found no significant main effect in reading comprehension, $F(2,309)=.35$, n.s., or reading vocabulary, $F(2,310)=2.22$, $n . s$. These findings suggest that opportunities solely to read 10 books or in combination with a family literacy intervention did not produce significant improvements in children's reading comprehension or vocabulary scores.

Given the low participation in the family literacy events, we re-analyzed the data based on received treatments rather than experimentally assigned conditions. To do this, we created non-attending $(n=194)$ and attending $(n=52)$ treatment groups based on whether or not children participated in the family literacy events. Thus, the non-attending treatment group included the 72 children in the family literacy intervention who attended 0 summer literacy events and the 122 children randomly assigned to the treatment condition; the attending group included only the 52 children experimentally assigned to the family literacy group who attended 1 or more summer literacy events. We aggregated data for children who were experimentally assigned to the treatment group and children who chose not to attend the family literacy events 
into a combined condition because both groups of these children received 10 books during summer vacation. The last two columns of Table 3 display descriptive statistics for the final sample of children in the non-attending and attending group who completed all pretests and posttests. When we compared pretest scores for children in the control group, non-attending group, and attending group, we found no significant group difference on the GMRT total score, $F(2,315)=1.38, p=.25$.

Based on these reconstituted groupings, we conducted ANCOVA on reading scores and found no significant treatment effects on each of the three GMRT posttests. Findings from these re-analyses provide additional evidence that the treatment and family literacy intervention did not significantly improve reading comprehension or vocabulary scores. However, these results should be interpreted with caution as they are subject to selection biases due to possible unobserved differences between non-attending and attending children in the family literacy events.

Question 2: Do children in the treatment group and the family literacy group report reading more books during summer vacation than the control group? Are there significant differences between the treatment group and the family literacy group?

Table 4 displays the percentage of children who reported reading $0-1$ book to 10 or more books by experimental condition. The descriptive statistics suggest that a majority of the treatment group and family literacy group read 6 to 10 books. In particular, $67 \%$ of the treatment group and $69 \%$ of the family literacy group reported reading 6 or more books compared to $46 \%$ of the control group. A Kruskal-Wallis test revealed a significant difference among the three conditions in the number of books children reported reading during summer vacation, $\chi^{2}(2,324)$ $=12.404, p<.001 . \quad$ Pairwise comparisons revealed significant differences favoring the treatment group over the control group, $\chi^{2}(1,212)=8.876, p<.01$, and the family literacy group 
over the control group, $\chi^{2}(1,222)=9.55, p<.01$. No significant difference, however, was found between the treatment group and the family literacy group, $\chi^{2}(1,214)=.013$, n.s. These findings suggest that opportunities solely to read 10 books or in combination with a family literacy intervention increased book reading activities during summer vacation.

We also re-analyzed the treatment effect on book reading using data from the nonattending group and the attending group. The last two columns of Table 4 display descriptive statistics on the percentage of children in the non-attending and attending group who read between 0 to 1 book and 10 or more books. A Kruskal-Wallis test revealed significant differences in book reading based on children's participation in the family literacy events, $\chi^{2}(2$, $324)=14.369, p<.001$. Follow-up tests revealed that children in the non-attending group read more books than the control group, $\chi^{2}(1,274)=8.81, p<.01$, and children in the attending group reported reading more books than the control group $\chi^{2}(1,160)=10.936, p<.001$. There were no significant differences, however, between the attending and the non-attending treatment group, $\chi^{2}(1,152)=1.312$, n.s. In sum, children in the attending and non-attending treatment group reported reading more books than the control group. However, caution should be exercised in interpreting these non-experimental results.

Question 3: Do children in the treatment group and the family literacy group report reading books more frequently with their parents during summer vacation than the control group? Are there significant differences between the treatment group and the family literacy group?

Table 5 presents the distribution of responses on the frequency with which children read books with their parents. A Kruskal-Wallis revealed no significant group difference on the survey questions asking children about the frequency with which they read books with their mother or father. These findings suggest that opportunities solely to read 10 books or in 
combination with a family literacy intervention did not increase the frequency with which children read books with their mother or father.

The last two columns in Table 5 display frequency distributions for children in the nonattending and attending groups on the measures of reading books with parents. There was a significant difference in the frequency with which children read books with their mothers, $\chi^{2}(2$, $322)=7.654, p=.022$. Pairwise comparisons using a Kruskal-Wallis test indicated that the children in the attending group read books more frequently with their mothers than the control group, $\chi^{2}(1,260)=7.854, p<.01$. In addition, there was a significant group difference in the frequency with which children read books with their fathers, $\chi^{2}(2,323)=9.034, p=.011$, favoring the children in the attending group over both the control group, $\chi^{2}(1,160)=7.962, p<$ .01 , and the non-attending group, $\chi^{2}(1,151)=5.57, p=.018$. These findings suggest that children who attended the family literacy events read books more frequently with their mother and father than the control group. As with the earlier re-analyses, caution should be exercised in interpreting these non-experimental results.

Question 4: After controlling for children's pretest vocabulary scores and English language learner status, which components of the intervention are associated with posttest reading comprehension and vocabulary scores?

We conducted correlational and multiple regression analyses to examine relationships among the reading scores and the three measureable components of the treatment and family literacy intervention. Table 6 displays intercorrelations among the reading scores, English language learner status, the number of books children read, the number of family literacy events children attended, and the text comprehensibility score. Among the components of the intervention, the number of books children read during the summer was positively correlated with posttest comprehension scores and text comprehensibility was positively correlated with 
both posttest comprehension and vocabulary scores. To isolate the relationship between each intervention component and posttest reading scores, we conducted two regression analyses.

First, Table 7 displays the results of a hierarchical regression analysis for posttest comprehension scores. Pretest vocabulary scores and English language learner status were entered in the first step, with a resulting $R^{2}$ of .52 . The variables representing each of the three intervention components were entered in the second step, resulting in $R^{2}=.61$. Adding these three variables in step 2 resulted in $\Delta R^{2}=.09, F(3,305)=22.262, p<.001$. After partialing out pretest vocabulary scores and English language learner status, the number of books children read in the summer and the text comprehensibility score were positively associated with posttest scores in comprehension. Comparison of the beta weights in the final model suggested that pretest vocabulary scores were the strongest predictors of comprehension posttests followed by text comprehensibility, English language learner status, and the number of books read.

Second, a summary of results from a regression analysis for vocabulary is displayed in Table 8. Pretest vocabulary scores and English language learner status were entered in the first step with a resulting $R^{2}=.67$. When the variables representing the three intervention components were included in step 2, the resulting $R^{2}$ was .68. Adding the three variables in step resulted in a $\Delta R^{2}=.01, F(3,306)=2.58, p<.10$. Among the intervention components, text comprehensibility remained a significant predictor of posttest scores in vocabulary. Comparison of the beta weights in the final regression model indicated that pretest vocabulary scores and English language learner status were the strongest predictors of vocabulary posttests. There was no significant relationship, however, between the number of books read and posttest vocabulary scores. The regression results involving vocabulary posttests were also replicated using total reading scores (comprehension and vocabulary) as the dependent variable. 
In sum, the regression results suggest that end of fourth-grade vocabulary scores and English language proficiency were the strongest predictors of posttest reading scores. In addition, children who received relatively well-matched books (i.e., books with readability levels at or below their reading ability) were predicted to make larger comprehension and vocabulary gains than children who received relatively difficult books (i.e., books with readability levels above their reading ability). Finally, the number of books read predicted posttest scores in comprehension but not in vocabulary.

\section{Discussion}

The purpose of this experiment was to replicate the effects of a voluntary summer reading intervention with a sample of low-income Latino children from language minority families. Our primary goal was to replicate results from our most recent experimental study, which compared outcomes for a control group and a treatment group which received books and oral reading and comprehension scaffolding lessons (Kim et al., 2008). In addition, we wanted to examine whether adding a parent training component during summer vacation could enhance treatment effects. Although children in the treatment and family literacy group reported reading more books than the control group, there was no significant effect on reading achievement. Why did the voluntary summer reading intervention, both with and without a parent training component, fail to replicate treatment effects on reading comprehension and vocabulary? There are important differences between our previous studies and the current study that inform this question.

First, our previous studies included mostly English proficient children who had better reading skills than the children in the current study. In our three previous studies, the children scored near the $50^{\text {th }}$ percentile on a standardized reading test and the majority of the children 
came from homes where English was the primary language spoken by their parents. In contrast, this study included mostly low-income Latino children from language minority families whose mean reading comprehension score was at the $24^{\text {th }}$ percentile at the end of fourth-grade. Fourthgrade children in the bottom quartile of a comprehension test are likely to have weaknesses in decoding, fluency, and vocabulary that originate in the early grades (Juel, 1988; Stanovich, 2000) and persist in the middle grades (Snow \& Biancarosa, 2003). Moreover, a majority of the sample included English language learners who underwent significantly larger reading losses during the summer than English proficient children. Even among a sample of low-income Latino children from language minority families, English language learners scored approximately one-fifth of a standard deviation lower on comprehension and vocabulary posttests than English proficient children. For low-income Latino children who are acquiring English language proficiency, an intervention that includes teacher-directed instruction right before summer vacation and expands access to books during the summer may be necessary but not sufficient for improving reading comprehension.

Although children in this study received teacher-directed comprehension instruction and 10 books to read during the summer, there was no improvement on posttest scores. In many ways, our results with the current sample of struggling readers in fourth-grade replicate results from our first experiment involving children in Grades 1 to 5 (Kim, 2007). In our first experiment, the effects of voluntary summer book reading were smallest among children in Grade $1(E S=-.01)$ and Grade $2(E S=.07)$. Similar to beginning readers, struggling readers in fourth-grade may also lack the decoding skills and reading fluency to benefit from a voluntary book reading intervention with no teacher-directed instruction during summer vacation. Since reading comprehension is the product of decoding and listening comprehension (Gough et al., 
1986), additional scaffolding that helps English language learners read unfamiliar words and hear and acquire the meaning of new words may be needed to promote stronger comprehension gains (Shanahan \& Beck, 2006).

Second, children in our two most recent experiments received books that were wellmatched to their reading level. In these two studies (Kim, 2006; Kim et al., 2008), we controlled text comprehensibility by using a computer algorithm that identified books that were matched to each child's reading level and preferences. As a result, all books were within each child's independent reading level. In contrast, children in this study attended a school bookfair and chose the books they received during the summer. The book fair introduced a greater mismatch between children's reading levels and the readability level of their books. Given the restricted range of the Lexile levels of the books relative to the Lexile level of the children, very few books were appropriately challenging for poor readers whereas most books were appropriately challenging for good readers. Overall, $67 \%$ of the children received books with negative text comprehensibility scores, suggesting that most children received difficult books with readability levels above their independent reading level. There was also a strong correlation between children's pretest comprehension scores and the text comprehensibility scores, suggesting that poor readers were more likely than good readers to receive books with readability levels above their reading level. Since incidental word learning through reading typically occurs when children read appropriately difficult text, poor readers who read difficult books are unlikely to improve their reading vocabulary and comprehension (R. C. Anderson et al., 1993).

\section{Future Research}

Findings from the regression analyses highlight several directions for future research. First, children's pretest vocabulary scores and English language proficiency at the end of fourth- 
grade explained over $50 \%$ of the variance in reading posttest scores. These results suggest that future intervention studies might couple efforts to improve vocabulary instruction and English language proficiency in an effort to prevent summer reading loss among low-income Latino children from language minority families.

Second, results from the regression analysis highlight the importance of the match between reader ability and the readability of texts. Controlling for pretest vocabulary scores and English language learner status, text comprehensibility was positively associated with posttest reading scores. Thus, children who received easy and well-matched books were predicted to make larger reading comprehension and vocabulary gains than children who received difficult books. Because Lexiles are based on the semantic and syntactic difficulty of text, children who received difficult books were exposed to a higher proportion of unfamiliar words and longer sentences than children receiving easy and well-matched books (U. S. Department of Education, 2001). Meta-analytic research on incidental word learning during independent reading suggests that children are less likely to learn new words when reading text with a large number of unknown words (Swanborn et al., 1999). A preponderance of unknown words in text may impede children's ability to read fluently (Mesmer \& Cumming, 2009), to process and retain the meaning of words in working memory (Just \& Carpenter, 1992), and to integrate words and information in text with prior knowledge (Nagy et al., 1987; Perfetti, Landi, \& Oakhill, 2007). Although findings from the regression analysis do not provide causal evidence on the effects text readability on reading comprehension, they underscore the importance of encouraging children to read appropriately challenging texts.

In addition, the regression analyses suggest that the number of books read during the summer was positively correlated with reading comprehension scores but not vocabulary scores. 
According to the Simple View of Reading (Gough \& Tunmer, 1986), reading comprehension depends on decoding ability and linguistic comprehension. Reading books that are appropriately challenging for one summer may help children practice decoding words and acquire knowledge of new words and concepts. Gains on a vocabulary assessment, however, may not emerge until children read books that are appropriately difficult for multiple summer vacations. Given the low probability of incidental word learning during independent reading (Swanborn \& de Glopper, 1999), children need massive exposure to print across multiple school years to enjoy vocabulary gains (Stanovich, 2000). In short, it is the cumulative effect of print exposure that promotes vocabulary growth. Ultimately, experimental evidence is needed to determine whether an intervention that increased the quantity of book reading over two or more summers and improved the quality of the match between readers and texts could improve both reading comprehension and vocabulary.

Finally, there was no evidence that attendance in the family literacy event was positively associated with reading comprehension and vocabulary scores. The only significant link between the family literacy activities and student outcomes emerged from our non-experimental comparisons, which showed that children who attended the family literacy events read books more frequently with their mother and father than control group children. Consistent with previous research (St. Pierre, Ricciuti, \& Rimdzius, 2005), findings from this study suggest that family literacy interventions that focus primarily on training parents do not reliably improve child outcomes. Perhaps, then, a more effective approach would involve training both parents and children and including teacher-directed vocabulary and comprehension lessons in a centerbased summer reading program. This strategy would have greater costs for schools and may limit the scalability of the intervention for large school districts. However, without a more 
effective summer reading intervention, many low-income Latino children from language minority families will continue to fall behind in reading during the elementary grades. 


\section{References}

Allen, L., Cipielewski, J., \& Stanovich, K. E. (1992). Multiple indicators of children's reading habits and attitudes: Construct validity and cognitive correlates. Journal of Educational Psychology, 84, 489-503.

Anderson, J. R. (1995). Learning and memory: An integrated approach. New York: Wiley.

Anderson, R. C., \& Nagy, W. E. (1993). The vocabulary conundrum. Washington, DC: Office of Educational Research and Improvement.

Anderson, R. C., Wilson, P. T., \& Fielding, L. G. (1988). Growth in reading and how children spend their time outside of school. Reading Research Quarterly, 23, 285-303.

Bowey, J. A., \& Muller, D. (2005). Phonological recoding and rapid orthographic learning in third-graders' silent reading: A critical test of the self-teaching hypothesis. Journal of Experimental Child Psychology, 92, 203-219.

Brynes, J. P. (2000). Using instructional time effectively. In L. Baker, M. J. Dreher \& J. T. Guthrie (Eds.), Engaging young readers (pp. 188-208). New York: Guilford Press.

Burkam, D. T., Ready, D. D., Lee, V. E., \& LoGerfo, L. F. (2004). Social-class differences in summer learning between kindergarten and first grade: Model specification and estimation. Sociology of Education, 77, 1-31.

California Department of Education. (1999). Reading/language arts framework for California public schools, kindergarten through grade twelve. Sacramento, CA: California Department of Education.

Carver, R. P. (1994). Percentage of unknown vocabulary words in text as a function of the relative difficulty of the text: Implications for instruction. Journal of Reading Behavior, 26, 413-437.

Carver, R. P., \& Leibert, R. E. (1995). The effect of reading library books at different levels of difficulty upon gain in reading ability. Reading Research Quarterly, 30, 26-48.

Chall, J. S. (1983). Stages of reading development. New York: McGraw-Hill.

Chin, T., \& Phillips, M. (2004). Social reproductive and child-rearing practices: Social class, children's agency, and the summer activity gap. Sociology of Education, 77, 185-210.

Clinard, L. (2002). Family time reading fun. Dubuque, IA: Kendall/Hunt Publishing Company.

Cooper, H., Nye, B., Charlton, K., Lindsay, J., \& Greathouse, S. (1996). The effects of summer vacation on achievement test scores: A narrative and meta-analytic review. Review of Educational Research, 66, 227-268.

Cunningham, A. E., \& Stanovich, K. E. (1990). Assessing print exposure and orthographic processing skill in children: A quick measure of reading experience. Journal of Educational Psychology, 82, 733-740.

Cunningham, A. E., \& Stanovich, K. E. (1991). Tracking the unique effects of print exposure in children: Association with vocabulary, general knowledge, and spelling. Journal of Educational Psychology, 83, 264-274.

Daane, M. C., Campbell, J. R., Grigg, W. S., Goodman, M. J., \& Oranje, A. (2005). Fourth-grade students reading aloud: NAEP 2002 special study of oral reading (NCES 2006-469). Washington, DC: U. S. Department of Education. Institute of Education Sciences, National Center for Education Statistics.

Debruin-Parecki, A. (2007). Let's read together. Baltimore, MD: Paul H. Brookes Publishing. 
Entwisle, D. R., Alexander, K. L., \& Olson, L. S. (2000). Summer learning and home environment. In R. D. Kahlenberg (Ed.), A notion at risk (pp. 9-30). New York: The Century Foundation Press.

Fry, E. (2002). Readability versus leveling. Reading Teacher, 56, 286-291.

Fuchs, L. S., Fuchs, D., Hosp, M. K., \& Jenkins, J. R. (2001). Oral reading fluency as an indicator of reading competence: A theoretical, empirical, and historical analysis. Scientific Studies of Reading, 5, 241-258.

Goldenberg, C., Rueda, R. S., \& August, D. (2006). Sociocultural influences on the literacy attainment of language-minority children and youth. In D. August \& T. Shanahan (Eds.), Developing literacy in second-language learners: Report of the national literacy panel on language minority children and youth (pp. 269-318). Mahwah, NJ: Lawrence Erlbaum Associates, Publishers.

Gough, P. B., \& Tunmer, W. E. (1986). Decoding, reading, and reading disability. Remedial and Special Education, 7, 6-10.

Heyns, B. (1978). Summer learning and the effects of schooling. New York: Academic Press, Inc.

Hofferth, S. L., \& Sandberg, J. F. (2001). How american children spend their time. Journal of Marriage and Family, 63, 295-308.

Juel, C. (1988). Learning to read and write: A longitudinal study of 54 children from first through fourth grades. Journal of Educational Psychology, 80, 437-447.

Just, M. A., \& Carpenter, P. A. (1992). A capacity theory of comprehension: Individual differences in working memory. Psychological Review, 99, 122-149.

Kim, J. S. (2006). The effects of a voluntary summer reading intervention on reading achievement: Results from a randomized field trial. Educational Evaluation and Policy Analysis, 28, 335-355.

Kim, J. S. (2007). The effects of a voluntary summer reading intervention on reading activities and reading achievement. Journal of Educational Psychology, 99, 505-515.

Kim, J. S., \& White, T. G. (2008). Scaffolding voluntary summer reading for children in Grades 3 to 5: An experimental study. Scientific Studies of Reading, 12, 1-23.

Koskinen, P. S., \& Blum, I. H. (1986). Paired repeated reading: A class strategy for developing fluent reading. Reading Teacher, 40, 70-75.

Lareau, A. (1989). Home advantage: Social class and parental intervention in elementary education. New York: The Falmer Press.

Maria, K., Hughes, K. E., MacGinitie, W. H., MacGinitie, R. K., \& Dreyer, L. G. (2007). Lexile conversions for the Gates-MacGinitie reading tests, 4th edition. Rolling Meadows, IL: Riverside Publishing.

Meichenbaum, D., \& Biemiller, A. (1998). Nurturing independent learners. Cambridge, MA: Brookline Books.

Mesmer, H. A. E., \& Cumming, S. (2009). Text-reader matching: Meeting the needs of struggling readers. In E. H. Hiebert \& M. Sailors (Eds.), Finding the right texts (pp. 149177). New York: Guilford Press.

Nagy, W. E., Anderson, R. C., \& Herman, P. A. (1987). Learning word meanings from context during normal reading. Reading Research Quarterly, 24, 237-270.

Nagy, W. E., \& Scott, J. A. (2000). Vocabulary processes. In M. L. Kamil, P. B. Mosenthal, P. D. Pearson \& R. Barr (Eds.), Handbook of reading research. Mahwah, NJ: Erlbaum. 
National Reading Panel. (2000). Teaching children to read: An evidence-based assessment of the scientific research literature on reading and its implications for reading instruction. Washington, DC: National Institute of Child Health and Human Development.

O'Brien, D. M. (1999). Three essays on early academic achievement of minority and disadvantaged students. Unpublished Dissertation for the Degree of Doctor of Philosophy in Political Economy, The University of Texas at Dallas, Dallas.

O'Connor, R., Bell, K. M., Harty, K. R., Larkin, L. K., Sackor, S. M., \& Zigmond, N. (2002). Teaching reading to poor readers in the intermediate grades: A comparison of text difficulty. Journal of Edcational Psychology, 94, 474-485.

Pearson, P. D., \& Fielding, L. (1991). Comprehension instruction. In R. Barr, M. L. Kamil, P. B. Mosenthal \& P. D. Pearson (Eds.), Handbook of reading research, volume II (pp. 815860). New York: Longman.

Perfetti, C. A., Landi, N., \& Oakhill, J. (2007). The acquisition of reading comprehension skill. In M. J. Snowling \& C. Hulme (Eds.), The science of reading: A handbook (pp. 227247). Malden, MA: Blackwell Publishing.

Phillips, M., \& Chin, T. (2004). How families, children, and teachers contribute to summer learning and loss. In G. Borman \& M. Boulay (Eds.), Summer learning: Research, policies, and programs (pp. 255-278). Mahwah, NJ: Lawrence Erlbaum Associates.

RAND Reading Study Group. (2002). Reading for understanding. Santa Monica, CA: RAND.

Rasch, G. A. (1980). Probabilistic models for some intelligence and attainment tests. Chicago: University of Chicago Press.

Rosenshine, B., \& Meister, C. (1994). Reciprocal teaching: A review of the research. Review of Educational Research, 64, 181-221.

Rosenshine, B., Meister, C., \& Chapman, S. (1996). Teaching students to generate questions: A review of the intervention studies. Review of Educational Research, 66, 181-221.

Rosenthal, R., \& Rosnow, R. L. (1991). Essentials of behavioral research: Methods and data analysis (2nd ed.). New York: McGraw-Hill.

Schnick, T., \& Knickelbine, M. (2000). The lexile framework, an introduction for educators. Durham, NC: Metametrics, Inc.

Shanahan, T., \& Beck, I. L. (2006). Effective literacy teaching for English-language learners. In T. Shanahan \& D. August (Eds.), Developing literacy in second-language learners (pp. 415-488). Mahwah, NJ: Lawrence Erlbaum Associates, Publishers.

Share, D. L. (1995). Phonological recoding and self-teaching: Sine qua non of reading acquisition. Cognition, 55, 151-218.

Snow, C. E., \& Biancarosa, G. (2003). Adolescent literacy and the achievement gap: What do we know and where do we go from here? New York: Carnegie Corporation of New York.

Stahl, S. A. (2004). What do we know about fluency? Findings of the National Reading Panel. In P. McCardle \& V. Chhabra (Eds.), The voice of evidence in reading research (pp. 187212). Baltimore: Paul H. Brookes Publishing Co.

Stanovich, K. E. (2000). Progress in understanding reading: Scientific foundations and new frontiers. New York: Guilford Press.

Swanborn, M. S. L., \& de Glopper, K. (1999). Incidental word learning while reading: A metaanalysis. Review of Educational Research, 69, 261-285.

U. S. Department of Education. (2001). Assessing the lexile framework: Results of a panel meeting, NCES 2001-08. Washington, DC: U. S. Department of Education, National Center for Education Statistics. 
Voluntary Summer Book Reading 33

Wright, B. D., \& Stone, M. H. (2004). Making measures. Chicago: The Phaneron Press, Inc. 


\section{Author Note}

James S. Kim, Harvard Graduate School of Education. Jonathan Guryan, University of Chicago Booth School of Business and NBER.

A preliminary version of this article was presented at the $15^{\text {th }}$ annual meeting of the Society for the Scientific Study of Reading, Asheville, NC in July 2008. We gratefully acknowledge the financial support of the William T. Grant Foundation. The first author also acknowledges support from a National Academy of Education Spencer Postdoctoral fellowship during the preparation of this manuscript. We thank Dr. Linda Clinard and staff at the California Reading and Literature Project (CRLP) at the University of California, Irvine for supporting the implementation of this study.

Correspondence concerning this article should be addressed to James S. Kim, Harvard Graduate School of Education, 14 Appian Way, Larsen 505, Cambridge, MA 02138. E-mail: james_kim@gse.harvard.edu 
Voluntary Summer Book Reading 35

Table 1

Pretest Demographic Characteristics of Children in the Final Sample $(N=325)$, by Condition

\begin{tabular}{lcccc}
\hline \multicolumn{1}{c}{ Characteristic } & $\begin{array}{c}\text { Control } \\
(\mathrm{n}=110)\end{array}$ & $\begin{array}{c}\text { Treatment } \\
(\mathrm{n}=103)\end{array}$ & $\begin{array}{c}\text { Family } \\
(\mathrm{n}=112)\end{array}$ & $\begin{array}{c}\text { Total } \\
(\mathrm{N}=325)\end{array}$ \\
\hline \% Female & 45 & 50 & 48 & 48 \\
\% Latino/a & 99 & 99 & 99 & 99 \\
\% Spanish is the primary language spoke at home & 91 & 98 & 96 & 95 \\
\% Living with two parents & 65 & 64 & 66 & 65 \\
\% Free lunch & 97 & 97 & 93 & 96 \\
\% English language learner & 68 & 73 & 79 & 73 \\
Age (Months) & $123(5.77)$ & $123(6.08)$ & $123(6.15)$ & $123(5.99)$ \\
\hline
\end{tabular}

Note. Age in months $=$ Standard deviations in parentheses. 
Voluntary Summer Book Reading 36

Table 2

Participation in Summer Literacy Events Among Children in the Family Literacy Group \begin{tabular}{ll} 
Total Events Attended & No. $\%$ \\
\hline
\end{tabular}

$\begin{array}{lll}0 & 62 & 55 \\ 1 & 21 & 19\end{array}$

$2 \quad 11 \quad 10$

$3 \quad 18 \quad 16$


Voluntary Summer Book Reading 37

Table 3

Means and Standard Deviations for GMRT Pretest and Posttest, by Condition

\begin{tabular}{|c|c|c|c|c|c|c|c|c|c|c|c|c|c|c|c|}
\hline \multirow[b]{2}{*}{ Measure } & \multicolumn{3}{|c|}{ Control } & \multicolumn{3}{|c|}{ Treatment } & \multicolumn{3}{|c|}{ Family Literacy } & \multicolumn{3}{|c|}{ Non-attending } & \multicolumn{3}{|c|}{ Attending } \\
\hline & $M$ & $S D$ & $n$ & $M$ & $S D$ & $n$ & $M$ & $S D$ & $n$ & $M$ & $S D$ & $n$ & $M$ & $S D$ & $n$ \\
\hline \multicolumn{16}{|l|}{ Pretest } \\
\hline Total Re & 26.38 & 20.67 & 107 & 23.30 & 17.86 & 102 & 23.52 & 18.27 & 109 & 22.23 & 16.65 & 164 & 27.57 & 21.89 & 47 \\
\hline Comp & 26.03 & 21.49 & 108 & 25.50 & 17.68 & 102 & 24.95 & 19.49 & 110 & 24.12 & 16.88 & 164 & 29.02 & 23.35 & 48 \\
\hline Vocabu & 29.10 & 21.92 & 108 & 24.10 & 19.32 & 102 & 24.63 & 18.77 & 110 & 23.33 & 18.07 & 164 & 27.94 & 21.71 & 48 \\
\hline \multicolumn{16}{|l|}{ Posttest } \\
\hline Total Read & 19.40 & 19.29 & 106 & 16.64 & 16.66 & 101 & 17.32 & 19.01 & 110 & 15.71 & 15.69 & 162 & 21.24 & 23.45 & 49 \\
\hline Comprehension & 21.07 & 19.58 & 108 & 19.78 & 18.05 & 101 & 18.98 & 20.90 & 110 & 18.31 & 17.30 & 162 & 22.84 & 25.53 & 49 \\
\hline Vocabulary & 20.96 & 21.54 & 108 & 16.87 & 17.67 & 103 & 18.29 & 19.71 & 110 & 16.30 & 16.58 & 164 & 21.96 & 24.28 & 49 \\
\hline
\end{tabular}

Note. GMRT = Gates MacGinitie Reading Test (National Percentile Rank). The non-attending group includes children originally assigned to the treatment group and children originally assigned to the family literacy group who attended 0 family literacy events. The attending group includes children originally assigned to the family literacy group who attended 1 or more family literacy event. 
Voluntary Summer Book Reading 38

Table 4

Percentage of Children Reading 0-1 Book to 10 or More Books, by Condition $(N=324)$

\begin{tabular}{lrrrrr}
\hline Category & $\begin{array}{r}\text { Control } \\
(\mathrm{n}=110)\end{array}$ & $\begin{array}{r}\text { Treatment } \\
(\mathrm{n}=102)\end{array}$ & $\begin{array}{r}\text { Family Literacy } \\
(\mathrm{n}=112)\end{array}$ & $\begin{array}{r}\text { Non-attending } \\
(\mathrm{n}=164)\end{array}$ & $\begin{array}{r}\text { Attending } \\
(\mathrm{n}=50)\end{array}$ \\
\hline (\%) 0-1 book & 17 & 6 & 4 & 5 & 2 \\
$(\%)$ 2-3 books & 17 & 6 & 13 & 10 & 10 \\
$(\%)$ 4-5 books & 19 & 22 & 14 & 20 & 10 \\
$(\%)$ 6-7 books & 10 & 18 & 17 & 16 & 20 \\
$(\%)$ 8-9 books & 10 & 16 & 18 & 16 & 18 \\
$(\%)$ 10 or more books & 26 & 33 & 34 & 32 & 40 \\
\hline
\end{tabular}

Note. The non-attending group includes children originally assigned to the treatment group and children originally assigned to the family literacy group who attended 0 family literacy events. The attending group includes children originally assigned to the family literacy group who attended 1 or more family literacy event. 
Voluntary Summer Book Reading 39

\section{Table 5}

Frequency Distributions for Reading Books with Parents Survey Data (\%), by Condition ( $N=$ 324)

\begin{tabular}{lccccc}
\hline \multicolumn{1}{c}{ Survey item } & $\begin{array}{r}\text { Control } \\
(\mathrm{n}=110)\end{array}$ & $\begin{array}{r}\text { Treatment } \\
(\mathrm{n}=102)\end{array}$ & $\begin{array}{r}\text { Family Literacy } \\
(\mathrm{n}=112)\end{array}$ & $\begin{array}{r}\text { Non-attending } \\
(\mathrm{n}=164)\end{array}$ & $\begin{array}{r}\text { Attending } \\
(\mathrm{n}=50)\end{array}$ \\
\hline 1. Read books with mother & & & & & \\
$\quad$ Never or hardly ever & 37 & 32 & 22 & 32 & 10 \\
Once or twice a month & 22 & 21 & 28 & 22 & 34 \\
Once or twice a week & 31 & 36 & 34 & 33 & 40 \\
$\quad$ Almost every day & 10 & 11 & 16 & 13 & 16 \\
2. Read books with father & & & & & \\
$\quad$ Never or hardly ever & 56 & 48 & 40 & 48 & 30 \\
Once or twice a month & 13 & 20 & 23 & 21 & 22 \\
Once or twice a week & 20 & 26 & 23 & 23 & 30 \\
Almost every day & 11 & 7 & 13 & 8 & 18 \\
\hline
\end{tabular}

Note. The non-attending group includes children originally assigned to the treatment group and children originally assigned to the family literacy group who attended 0 family literacy events. The attending group includes children originally assigned to the family literacy group who attended 1 or more family literacy event. 
Table 6

Intercorrelations Among the Major Variables $(N=309)$

\begin{tabular}{|c|c|c|c|c|c|c|c|}
\hline Variables & 1 & 2 & 3 & 4 & 5 & 6 & 7 \\
\hline 1. GMRT comprehension (posttest) & -- & & & & & & \\
\hline 2. GMRT vocabulary (posttest) & $.70 * *$ & -- & & & & & \\
\hline 3. GMRT vocabulary (pretest) & $.70 * *$ & $.79 * *$ & -- & & & & \\
\hline 4. English language learner & $-.51 * *$ & $-.58 * *$ & $-.51 * *$ & -- & & & \\
\hline 5. Number of books read & $.12 *$ & -.01 & .05 & .06 & -- & & \\
\hline 6. Number of family literacy events attended & .03 & .06 & .02 & -.04 & $.14^{*}$ & -- & \\
\hline 7. Text comprehensibility & $.68 * *$ & $.58 * *$ & $.61 * *$ & $-.48 * *$ & .05 & -.03 & -- \\
\hline
\end{tabular}

Note. GMRT $=$ Gates MacGinitie Reading Test

$\sim p<.10, * p<.05, * * p<.01$ 
Voluntary Summer Book Reading 41

Table 7

Hierarchical Regression Analyses for Variables Predicting Posttest Comprehension Scores $(N=$ 311)

\begin{tabular}{lrrrrr}
\hline \multicolumn{1}{c}{ Variable } & $B$ & $S E B$ & $\beta$ & $R$ & $R^{2}$ \\
\hline Step 1 & & & & & \\
$\quad$ Pretest reading vocabulary & .54 & .04 & $.59^{* *}$ & & \\
English language learner & -13.37 & 2.89 & $-.21^{* *}$ & .722 & .521 \\
Step 2 & & & & & \\
$\quad$ Pretest reading vocabulary & .37 & .04 & $.40^{* *}$ & & \\
English language learner & -9.02 & 2.74 & $-.14^{* *}$ & & \\
Number of books read & 1.65 & .60 & $.10^{* *}$ & & \\
Number of family literacy events attended & .71 & 1.28 & .02 & & \\
Text comprehensibility & .07 & .01 & $.35^{* *}$ & .779 & .607 \\
\hline
\end{tabular}

Note. $B=$ unstandardized regression coefficient, $S E=$ standard error, $\beta=$ standardized regression coefficient. $\sim p<.10, * p<.05, * * p<.01$ 
Voluntary Summer Book Reading 42

Table 8

Hierarchical Regression Analyses for Variables Predicting Posttest Vocabulary Scores $(N=$ 312)

\begin{tabular}{lrrrrr}
\hline \multicolumn{1}{c}{ Variable } & \multicolumn{1}{c}{$B$} & $S E B$ & $\beta$ & $R$ & $R^{2}$ \\
\hline Step 1 & & & & & \\
$\quad$ Pretest reading vocabulary & .69 & .04 & $.66^{* *}$ & & \\
English language learner & -18.22 & 2.74 & $-.25^{* *}$ & .819 & .671 \\
Step 2 & & & & & \\
Pretest reading vocabulary & .64 & .05 & $.62^{* *}$ & & \\
English language learner & -16.07 & 2.83 & $-.22^{* *}$ & & \\
Number of books read & -.73 & .63 & -.04 & & \\
Number of family literacy events attended & 1.74 & 1.33 & .04 & & \\
Text comprehensibility & .02 & .01 & $.10^{*}$ & .824 & .679 \\
\hline
\end{tabular}

Note. $B=$ unstandardized regression coefficient, $S E=$ standard error, $\beta=$ standardized regression coefficient. $\sim p<.10, * p<.05, * * p<.01$ 